of one crop, einkorn, in southeast Turkey agrees well with archaeobotanical evidence. Whether other crops were domesticated in the same part of the Fertile Crescent remains to be established.

\author{
Mark Nesbitt \\ Delwen Samuel \\ Instituce of Archaeology, \\ University College London, \\ London WCIH OPY, United Kingdom \\ E-mail:d.samuel @ud.ac.uk
}

\section{Wheat Domestication: Archaeobotanical Evidence}

Genetic evidence of Manfred Heun et al. (Reports, 14 Nov, p. 1312) for einkorn wheat domestication in soucheast Turkey has been countered by Martin K. Jones et al. (Letters, 16 Jan., p. 302). Jones et al. cite evidence that agriculture began earlier in the southern Levant and that einkom was one of the original domesticates there. Recent archaeobotanical work does not support the picture presented by Jones et al.

Archaeological plant remains from.four pre-pottery Neolithic A (1) sites are said by Jones et al. to indicate domestication of einkorn, emmer, and barley in the southern Levant at about 8000 to 7700 years B.C. (radiocarbon-dated). Einkorn is absent from all four sites and from the earlier site of Ohalo Il (17,000 B.C.) in the same region (2). There is no evidence for domesticated plants in the PPNA levels of Jericho, Netiv Hagdud, and Gilgal (3). The earliest level (IA) of Aswad (7800 to 7600 B.C.) contains emmer and barley that may be domesticated (4). Domesticated einkorn does not appear in the region until the PPNB, at Jericho (7300 B.C.) and level Il at Aswad (6900 B.C.).

In contrast, both wild and domesticated einkorn and emmer are present at early agricultural sites in the northern Fertile Crescent of sourheasr Turkey and northern Syria dating from 7700 to 7500 B.C. (5). Wild einkorn is also present in pre-agricultural levels of sites in this region, including Mureybit (8500 B.C.) (6), phase 1 of Abu Hureyra (9500 to 8000 B.C.) (7), Dja'de (9600 B.C.), and Jerf al Ahmar (9800 BC) (8). This fits well with the current-day distribution of wild einkorn, abundant in the northern Fertile Crescent, but virtually absent from the southern Levant (9). Study of seeds and charcoal from early Holucene sites in souchwest Asia confirms that vegetation at this period was similar to current-day potential vegetation(10).

In view of the small number of excavated sires and the large error limits associated with Neolithic radiocarbon dates, current architerbotanical evidence dues not allow localization of agriculcural origins to any one subregion within the fertile crescent. How ever, the generic evidence for domestication

\section{References and Notes}

1. The earliest Neolithic of southwest Asia is divided into the PPNA ( 8300 to 7600 B.C.) and the PPNB (7600 10 6000 B.C.) periods.

2. M. E. Kislev, D. Nadel, I. Carmi, Rev. Palaeobot Palynol. 73, 161 (1992)

3. Plant remains from the PPNA levels at Jericho consist of fragmented grains of emmer and barley of undetermined wild or domesticaled status, dating to about 7500 B.C. (M. Hopl, in Jericho, K. Kenyon and T. A. Holland. Eds. (British School of Archaeology in Jerusalem, London, 1983), vol. 5 pp. 576-621]. The only cereal remains at Netiv Hagdud (7700 to 7400 B.C.) are of wild barley [M. E. Kislev, in An Early Neolithic Village in the Jordan Valley, O. Bar-Yosef and A. Gopher. Eds. (Peabody Museum of Archaeology and Ethnology, Harvard Univ., Cambridge, MA. 1997), pp. 209-236]. Plant remains from the nearby site of Gilgal are unpublished and therelore of uncertain stalus.

4. W. van Zeist and J. A. H. Bakker-Heeres, Palaeohistoria 24, 165 (1982).

5. Domesticated einkorn, emmer, and barley are reported from Cafer Höyük at 7500 BC [D. de Mou. lins, Cah. Euphrate 7, 191 (1993)] and from Abu Hureyra at 7700 B.C. (phase 2A) [D. de Moulins, Agricultural Changes at Euphrates and Steppe Sites in the Mid-8th to the Gith Millennium B.C. (Britsh Archaeological Reports, int. Ser 683, Oxford, 1997)].

6 W. van Zeist and J. A. H. Bakker-Heeres, Palaeohistoria 26, 171 (1984).

7. G. C. Hillman. S. M. Colledge, D. R. Harris, in Foraging and Farming: The Evolution of Plant Exploitation, D. R. Harris and G. C. Hillman. Eds. (Unwin Hyman, London, 1989), pp. 240-268.

8. G. Willcox. Veg. Hist. Archaeobot. 5. 143 (1996)

9. D. Zohary and M. Hopf, Domestication of Plants in the Olo World (Clarendon, Oxlord, 1993).

10. G. C. Hillman, in The Origins and Spread of Agriculture and Pastoralism in Eurasia. D. R. Harris, Ed. (Univ. College Loridon, London, 1996). pp. 159203
Correction: Note that the Dja'de and Jerf al Ahmar radiocarbon dates are mistakenly given as B.P. dates. The dates are in fact 7650 B.C. and 7850 B.C. 